\title{
EDITORIAL
}

\section{Breast tumors: of mice and women}

\author{
Sean P McDermott and Max S Wicha* \\ See related research by Lim et al., http://breast-cancer-research.com/content/12/2/R21
}

\begin{abstract}
For the past 20 years the mouse has served as a workhorse for studying the molecular underpinnings of human breast cancer. While some genetically engineered mouse mammary tumor models do not accurately recapitulate human disease (that is, the MMTV-Neu model and HER2-overexpressing human cancers), additional tumor models exist for studying the initiation, progression, and treatment of human breast cancer. The relationships between normal mouse mammary epithelial cells and tumor cells, however, have remained poorly defined. A recent article in Breast Cancer Research has shed light on these relationships.
\end{abstract}

In the previous issue of Breast Cancer Research, Lim and colleagues separated the various cellular components of the mouse mammary gland - including mammary stem cells (MaSCs), luminal progenitor cells, and differentiated luminal cells - to compare normal mouse and human mammary epithelial cells and various mouse tumors at the transcriptome level [1]. These results shed light on the remarkable conservation of signaling pathways in mouse and human breast cells, and potentially predict which cells may be the cell of origin for different breast tumors. Identification of the pathways in the various cellular components, such as IL-8 signaling in the MaSC, paves the way to develop eradication strategies against these cells.

While the human and mouse breast tissues exhibit distinct structural differences, there is increasing evidence of similar cellular hierarchies in both species [2]. In recent years, numerous groups have reported the isolation and functional characterization of these cells from mouse and human breast tissue [3-5]. From these studies, it was shown that the MaSC lies at the apex and can differentiate to produce luminal or myoepithelial progenitor cells, which generate the mature ductal,

*Correspondence: mwicha@umich.edu

University of Michigan, Comprehensive Cancer Center, 1500 E Medical Center Drive, 6303 Comprehensive Cancer Center, Ann Arbor, MI, 48109, USA alveolar, and myoepithelial cells that comprise the ductal epithelial network. Similarly, we previously identified a rare cell population - termed cancer stem cells (CSCs) in human breast tumors able to initiate and sustain tumorigenesis in immunocompromised NOD/SCID mice, indicating that a similar hierarchy exists in breast cancer [6].

Human breast cancer is a histologically, molecularly, and epidemiologically heterogeneous disease. There are six molecular subtypes based on gene expression analysis, which include normal breast-like, luminal A, luminal B, basal-like, claudin-low, and HER2/ERBB2 overexpressing [7-9]. The molecular heterogeneity among breast cancers has been suggested to result from different targets of transformation (that is, cell of origin), which has direct implications for prevention, detection, and treatment of breast cancer. Indeed, Lim and colleagues previously reported an increase in luminal progenitor cells in women heterozygous for BRCA1 mutations and demonstrated that these tumors were more similar at the transcriptome level to luminal progenitors than the MaSC-enriched population [5]. Additionally, the human MaSC-enriched fraction was more similar to claudin-low and normal breast-like tumors, suggesting the distinct molecular subtypes may derive from distinct cell types.

Building upon these studies, Lim and colleagues isolated by flow cytometry the analogous mouse mammary cell subtypes (MaSC-enriched, luminal progenitor, mature luminal, and stromal) using CD24, CD29, and CD61 expression, and defined gene expression profiles of these populations using microarray analysis [1]. Remarkably, comparison with previous expression profiling of human mammary epithelial cell subtypes showed conservation of gene expression patterns between the two species. Perhaps reflecting the inability to further fractionate the MaSCenriched fraction, which includes basal progenitor and mature myoepithelial cells due to common cell-surface molecules, it is not surprising that this fraction had the largest number of conserved genes (489 upregulated and 428 downregulated).

As with any gene expression study, the ability to tease apart the signaling pathways represents a potential roadblock. Lim and colleagues used Ingenuity Pathway Analysis, a manually collated database, to identify 
conserved networks in the MaSC-enriched, luminal progenitor, and mature luminal subpopulations. Prominent within the MaSC-enriched signature were ephrin, integrin, IL-8, p53, and Wnt signaling pathways. Additionally, some epithelial-mesenchymal transition (EMT) markers (Slug, Twist2, vimentin) were identified. The acquisition of an EMT phenotype has been suggested to contribute to metastasis [10], and the observation that cells undergoing EMT were enriched for and had characteristics of breast CSCs was recently harnessed to identify potential anti-CSC agents [11]. Whether breast tumor cells expressing these genes acquired basal cell characteristics rather than EMT, however, remains to be determined.

To extend upon their previous studies comparing normal human cell subpopulations with the six molecular subtypes of breast cancer [5], Lim and colleagues compared the four mouse cell subsets with six genetically engineered mouse mammary tumor models: $M M T V$ Wnt1, MMTV-Neu, MMTV-PyMT, WAP-Myc, WAPInt3 (Notch-1), and p53-null [1]. The gene signature from the MaSC-enriched subset was enriched in MMTV-Wnt1 and p53-null tumors, whereas the luminal progenitor signature was higher in MMTV-Neu and MMTV-PyMT tumors and the mature luminal signature was most similar to the $M M T V-M y c$ tumors. While these expression data are suggestive of the cell of origin for the various breast cancers, they may reflect an expansion of a particular cell type during tumor progression. Indeed, Cho and colleagues recently reported that MMTV-Wnt1 mouse breast tumors contain Thy $1^{+} \mathrm{CD} 24^{+}$tumorinitiating cells. Microarray analysis of this population defined a gene expression profile of which the orthologs predicted survival in breast cancer patients [12]. Further studies using overexpression of these oncogenes in the various purified breast epithelial cell types may help identify the true cell of origin for breast cancer similar to studies carried out in murine leukemias with hematopoietic stem and progenitor cells $[13,14]$.

In summary, the results of Lim and colleagues highlight the development of new approaches to understand the role of various cell types in breast tumor initiation and demonstrate that mouse tumor models may be useful in screening new breast cancer therapeutics. Moreover, the conservation of signaling pathways between mouse and human may facilitate the identification of valuable targets for therapeutic development. Using similar gene expression studies of breast cancer cells, we identified IL-8 signaling in breast CSCs and showed that the CXCR1 (IL-8 receptor) inhibitor repertaxin is able to target breast cancer stem cells [15]. It remains to be determined whether other signaling pathways identified by Lim and colleagues in MaSCs, luminal progenitor cells (that is, CXCR4 or KIT), or mature luminal cells can be successfully targeted in breast cancer.

\section{Abbreviations}

CSC, cancer stem cell; EMT, epithelial-mesenchymal transition; IL, interleukin; MaSC, mammary stem cell; MMTV, mouse mammary tumor virus.

\section{Competing interests}

MSW holds equity in Oncomed Pharmaceuticals, which holds a patent related to cancer stem cell models.

Published: 27 May 2010

\section{References}

1. Lim E, Wu D, Pal B, Bouras T, Asselin-Labat ML, Vaillant F, Yagita H, Lindeman GJ, Smyth GK, Visvader JE: Transcriptome analyses of mouse and human mammary cell subpopulations reveals multiple conserved genes and pathways. Breast Cancer Res 2010, 12:R21.

2. Visvader JE: Keeping abreast of the mammary epithelial hierarchy and breast tumorigenesis. Genes Dev 2009, 23:2563-2577.

3. Shackleton M, Vaillant F, Simpson KJ, Stingl J, Smyth GK, Asselin-Labat ML, Wu L, Lindeman GJ, Visvader JE: Generation of a functional mammary gland from a single stem cell. Nature 2006, 439:84-88.

4. Stingl J, Eirew P, Ricketson I, Shackleton M, Vaillant F, Choi D, Li HI, Eaves CJ: Purification and unique properties of mammary epithelial stem cells. Nature 2006, 439:993-997.

5. Lim E, Vaillant F, Wu D, Forrest NC, Pal B, Hart AH, Asselin-Labat ML, Gyorki DE, Ward T, Partanen A, Feleppa F, Huschtscha L I, Thorne HJ, Fox, SB, Yan M, French JD, Brown MA, Smyth GK, Visvader JE, Lindeman GJ: Aberrant luminal progenitors as the candidate target population for basal tumor development in BRCA1 mutation carriers. Nat Med 2009, 15:907-913.

6. Al-Haij M, Wicha MS, Benito-Hernandez A, Morrison SJ, Clarke MF: Prospective identification of tumorigenic breast cancer cells. Proc Natl Acad SciU S A 2003, 100:3983-3988

7. Perou CM, Sorlie T, Eisen MB, van de Rijn M, Jeffrey SS, Rees CA, Pollack JR, Ross DT, Johnsen H, Akslen LA, Fluge O, Pergamenschikov A, Williams C, Zhu SX, Lonning PE, Borresen-Dale AL, Brown PO, Botstein D: Molecular portraits of human breast tumours. Nature 2000, 406:747-752.

8. Herschkowitz JI, Simin K, Weigman VJ, Mikaelian I, Usary J, Hu Z, Rasmussen KE, Jones LP, Assefnia S, Chandrasekharan S, Backlund MG, Yin Y, Khramtsov AI Bastein R, Quackenbush J, Glazer RI, Brown PH, Green JE, Kopelovich L, Furth PA, Palazzo JP, Olopade OI, Bernard PS, Churchill GA, Van Dyke T, Perou CM: Identification of conserved gene expression features between murine mammary carcinoma models and human breast tumors. Genome Biol 2007, 8:R76.

9. Sorlie T, Perou CM, Tibshirani R, Aas T, Geisler S, Johnsen H, Hastie T, Eisen MB, van de Rijn M, Jeffrey SS, Thorsen T, Quist H, Matese JC, Brown PO, Botstein D, Eystein Lonning P, Borresen-Dale AL: Gene expression patterns of breast carcinomas distinguish tumor subclasses with clinical implications. Proc Natl Acad Sci U S A 2001, 98:10869-10874.

10. Mani SA, Guo W, Liao MJ, Eaton EN, Ayyanan A, Zhou AY, Brooks M, Reinhard F, Zhang CC, Shipitsin M, Campbell LL, Polyak K, Brisken C, Yang J, Weinberg RA: The epithelial-mesenchymal transition generates cells with properties of stem cells. Cell 2008, 133:704-715.

11. Gupta PB, Onder TT, Jiang G, Tao K, Kuperwasser C, Weinberg RA, Lander ES: Identification of selective inhibitors of cancer stem cells by highthroughput screening. Cell 2009, 138:645-659.

12. Cho RW, Wang X, Diehn M, Shedden K, Chen GY, Sherlock G, Gurney A, Lewicki J, Clarke MF: Isolation and molecular characterization of cancer stem cells in MMTV-Wnt-1 murine breast tumors. Stem Cells 2008, 26:364-371.

13. Krivtsov AV, Twomey D, Feng Z, Stubbs MC, Wang Y, Faber J, Levine JE, Wang J, Hahn WC, Gilliland DG, Golub TR, Armstrong SA: Transformation from committed progenitor to leukaemia stem cell initiated by MLL-AF9. Nature 2006, 442:818-822

14. Cozzio A, Passegue E, Ayton PM, Karsunky H, Cleary ML, Weissman IL: Similar MLL-associated leukemias arising from self-renewing stem cells and shortlived myeloid progenitors. Genes Dev 2003, 17:3029-3035.

15. Ginestier C, Liu S, Diebel ME, Korkaya H, Luo M, Brown M, Wicinski J, Cabaud O, Charafe-Jauffret E, Birnbaum D, Guan JL, Dontu G, Wicha MS: CXCR1 blockade selectively targets human breast cancer stem cells in vitro and in xenografts. J Clin Invest 2010, 120:485-497.

doi:10.1186/bcr2569

Cite this article as: McDermott SP, Wicha MS. Breast tumors: of mice and women. Breast Cancer Research 2010, 12:108. 